\title{
“The Closest Thing to God”: Post-industrialization and Postmodernism in Tawni O’Dell’s Coal Run
}

\author{
Charles Cullum \\ Worcester State University, Worcester, USA
}

\begin{abstract}
A growing body of American literature examines the conditions in towns from the Midwest to the Northeast that have been drastically affected by the condition of what has been termed “deindustrialization”. These towns have witnessed the employee downsizing and the eventual collapse of their major industries, such as automobile manufacturing and coal mining, and the fiction about them-termed “deindustrialization literature” by Sherry Lee Linkon-explores how the affected generations cope with these changed circumstances. The novel Coal Run, written in 2004 by Tawni O’Dell's, herself a native of a coal mining region in Western Pennsylvania, is one such example of deindustrialization literature and the focus of this essay. Set in a coal mining town that has been shut down because of a Centralia-like uncontrolled mine fire that opens fissures to a literal kind of hell, the protagonist, Ivan the Great, a former Penn State football star, and other characters attempt to re-orient themselves after the mine-described by Ivan as "the closest thing I had to God"—closes and the effects of that closing are felt. This paper discusses the motifs of ecological ruin, economic disruption, and personal, familial, and community disorientation in the novel. In doing so, the paper considers connections between de- or post-industrialization and postmodernism, particularly as discussed by cultural geographer David Harvey in The Condition of Postmodernity in terms of "the crisis tendency" of capitalism toward "overaccumulation" and the "link between postmodernism and...more flexible modes of capital accumulation”. The paper goes on to consider the experiences through which the novel's characters learn to look to the future in ways that may be said to coincide with the ethos of much postmodern American fiction that sets less ambitious but nonetheless still meaningful expectations for human being.
\end{abstract}

Keywords: deindustrialization literature, post-industrialization, postmodernism, American fiction, contemporary fiction

\section{Introduction: Deindustrialization Literature}

Since the 1970's, a large part of the United States from the Midwest to the Northeast has gone through a period of downsizing and closing of major industries such as automobile manufacturing, steel production, and coal mining. This "deindustrialization" has affected both urban areas, such as Detroit, Youngstown, and Pittsburgh, and also rural areas, such as the Monongahela River Valley through north central West Virginia and southwestern Pennsylvania. In response to this social, economic, and cultural shift, contemporary American

Charles Cullum, Ph.D., professor, Department of English, Worcester State University.

Correspondence concerning this article should be addressed to 486 Chandler Street, Worcester, MA. E-mail: Charles.Cullum@worcester.edu. 
writers are addressing the issues facing the generation who have inherited these changed circumstances in what Sherry Lee Linkon (2014) has termed “deindustrialization literature” (p. 39). Tawni O’Dell’s 2004 novel Coal Run captures the essence of the situation facing these individuals and communities.

Throughout the novel, characters struggle to make the transition from an industrial to a post-industrial society and personal life. In discussing this transition, it is helpful to make use of the distinction that urban sociologist Alice Mah makes between "industrial ruins" and "industrial ruination”. In her 2013 study, Life Among the Ruins: Deindustrialization in Historio-Graphical Perspective, Mah says that "Industrial ruins” are the "physical remains of industrial production: abandoned infrastructure, boarded-up buildings, derelict machinery, fenced-off fields” (Parnaby, 2013, p. 280). "Industrial ruination”, on the other hand, according to Mah connotes these ruins' "connections to the communities and memories within which they rest" (Parnaby, 2013, p. 280). Coal Run is a coal town that exists in both of these senses. It is a physical ruin. The town, which sat over the mine, had to be abandoned after the fire started by the major explosion deep in the mine was discovered some years later as the fire, as in Centralia, Pennsylvania, pushed its way to the surface. The local junkyard still has active fissures through which, in a kind of literal glimpse into hell, one can feel the heat escaping and see the smoke and even the actual fire below. At the same time, the memory and the economic, social, and personal consequences of the mine and the way of life that resulted from and around it, continue to permeate virtually every aspect of the existence of the people who survive the mine explosion and eventual closing.

While the novel explores this ruination in the lives of the generation of characters who were fully invested in the time of industrial production, that is, the older generation, the main focus is on those characters who are in the process of attempting to find focus for their lives in the aftermath of the industrial era, or the younger generation of the post-industrial era. And, in fact, Sherry Lee Linkon (2014) defines "deindustrialization literature" specifically as having those two attributes: "temporally—produced after 2000—and thematically—emphasizing the focus" of what she terms the "half-life", or "long-term legacy", of deindustrialization, "rather than the immediate experience" of that deindustrialization (pp. 39-40). Thus, the writers of this fiction themselves, Linkon (2014) observes, "occupy.... middle space”, and they create "imaginative texts that explore the interactions of early 21 st century characters with both the memory of industrial work and, more often, the decaying landscapes and experiences of struggle left behind by deindustrialization” (p. 39).

\section{Deindustrialization and Its Effects in Coal Run}

Coal Run begins in precisely this kind of “middle space” realm. The protagonist, Ivan Zoshenko, remembers the day of the massive mine blast that took the lives of his father, his uncle, his grandfather, and 94 other miners. As a child of six, he was awoken by the explosion and dragged by the arm by his mother across two miles of rough roadway to the entrance to the mine, where families from the entire town rushed for news of the fate of their family's miners. The mine itself and the local mining industry never recover from that explosion, and the rest of Ivan's adolescence and younger adulthood evolves in the ruins and ruination of the once overwhelmingly dominant center of everyone's life, the mine, what Ivan remembers as "the closest thing I had to God" (O'Dell, 2004, p. 138).

However, if the mine is God-like, it is a harsh and demanding God. The miners go to work when it is "still night, black and cold and silent", they chew tobacco in order to "lubricate their throats against the gritty coal dust", and they carry "lunch pails the size of tool boxes" in order to include extra sandwiches in case that day is the one when they get trapped in the mine (p. 1). The miners are always aware, as Ivan's father emphasizes to him, 
that in the mine there is only "one way in and one way out" (p. 4). In the aftermath of the explosion, the remains of only 64 of the 97 dead miners are identified, many of those by just a single body part, such as a foot in a recognizable boot.

While Ivan may see the mine as a kind of God figure, he and everyone else in the region nonetheless knows that there is a more earthly power behind that deity, namely, the J and P Coal Company and its owner, Stan Jack, who named the Coal Run mine after his mother, Gertrude, and so the miners nickname the mine "Gertie". But there is nothing familial in the way the company and Stan Jack run the mine. As Ivan looks at a photograph of the $\mathrm{J}$ and P company store from 1915, he remembers the history of the store's exploitative business practice of charging 25\% more than other stores, requiring the miners to buy their goods at the company store or be fired, and then providing them credit, with the result that "miners ended up so far in debt that they could never leave the coalfields” (p. 148). The contemporary company has not changed much. After the mine explosion, it arranges for a newspaper story and photo-op about their presenting "a gigantic...cardboard check" to a representative "widow" and "her four kids", but the newspaper story does not mention that the check "only contained 300 dollars for each family" (p. 299). And while local companies and individuals donated services, materials, and even the land for the burial of the dead miners, J and P Coal did not donate anything for the burial, and even "post[ed] a memo" at the mine office reminding the families that the company "was no longer obligated to provide money for burial costs, since the union had voted against the mandatory burial fund” (p. 220). Finally, when the mine fire finally breaks through to the surface of the town, the federal and state governments and Penn State University's mining-engineering department send "scientists and engineers" to investigate, but "no one from J \& P [Coal Company] put in an appearance" (p. 129). The federal government, not the coal company, buys out the houses of the townspeople who are displaced by the mine fire.

Going beyond the deleterious effects of industrialization on individuals and families, the negative effects on their natural environment are even more obvious. The continuous fire in the abandoned mine is emblematized most dramatically by the former town's junkyard area, termed "nature's version of a haunted house” (p. 317), where the air reeks of sulfur and the earth is pitted with "four-hundred-foot deep fiery sinkholes" (p. 317). In addition, there is an area of abandoned strip mining that is "as barren and lifeless as photos sent home from the Mars probe" (p. 222). And "Years after its closing", in the area around the factory of the former tire manufacturer, Franklin Tires, "the subtle reek of chemicals and burned rubber still lingers” (p. 80).

Along with the destruction of the natural environment, industrialization has left the region's human-made environment in ruins as well. The town of Coal Run itself shows the neglect of desertion in its "abandoned ball field scarred with gopher holes, ... [the] boarded-up elementary school, [and] a drive-in theater where rows of rusted speaker posts stand attention in the weeds like a suicide cult waiting for instructions from the great peeling white screen” (p. 120). In Centres burg, the larger town near Coal Run, the "buildings and structures” (p. 29) of industries sit empty and decaying. The Packard Mining Equipment plant that once produced "gigantic drill bits and colossal cogs and gear wheels" now "sits...[a] silent, burned-out shell” next to Franklin Tire's "smokeless smokestacks", and at the rail yard "rust-streaked coal cars sit beneath the disintegrating metal mouths of giant loading tipples waiting for a final run that's never going to happen” (p. 29).

However, notwithstanding the harshness of the work in the mine for the miners and the effects of the economic motivations of the mine owners on the miners and their families and on the ecology of the region, there can be no doubt that there was a mutual commitment of all parties to industrialization. The miners accept the rigors and dangers of the job because the money was good. This acceptance can be seen most emphatically in the 
implementation of the new equipment by the mine owners that most probably leads to the mine explosion. Specifically, they bring into the mines what are called "continuous miners", "large, steel-toothed cutting machines that ripped the coal directly from the face [of the mine surface] and dumped in onto conveyor belts that led to shuttle cars on the tracks” (p. 59). These new machines would eliminate some jobs, and, even more concernedly, "left more cracks in the ceilings where methane could escape into the air, creating a lethal combination for the smallest spark to ignite" (p. 59). The miners' union complains to the coal company about the use of these machines, but the company responds that the union is "exaggerating the safety issue" (p. 59). And so the union "backed off" because "no one was sure of the legality of striking because your company wanted to update its equipment and improve its output... what were the chances of winning a fight against progress?” (p. 59). Ivan, as a child at the time, was not involved in the issue directly, but nonetheless suffers from a sense of collective responsibility: "Gertie made me feel ashamed because I was a part of us, and we had allowed something terrible to happen to us” (p. 60).

This collective responsibility, specifically, among corporations, government, and organized labor, for the rise of the industrial era in America, and, in particular for its "phenomenal growth" after World War II (Harvey, 1990, p. 132), is discussed explicitly by cultural geographer David Harvey in his comprehensive examination of the economic and cultural history of the postmodern, The Condition of Postmodernity. He argues that these three entities achieved a "balance of power" of their interests and roles in maintaining and increasing capitalist modes of production. Unions, for their part, made significant gains in wages and benefits during the post-war period in industries across the mid-west and northeast by "adopting a collaborative stance with respect to Fordist—by which Harvey means technologically based—production techniques and cognate corporate strategies to increase productivity” (p. 133).

Ivan's point about the culpability of the miners in their own demise is, therefore, founded on economic history and principles. More to the point of the novel's treatment of these issues, though, Harvey's argument about the balance of power and interests within capitalist industrialization reinforces the clear role and identity of the older generation of industrial era miners. They are labor to the company's management. There is no doubt about what they will do and who they are. This attitude is seen most graphically in the character of Rado Zoshenko, Ivan's father. He emigrated to the United States after World War II from the Ukraine. During the war, he was impressed to mine uranium in a Soviet work camp, where he suffered great physical and mental privation for four years. When Ivan's mother first meets Rado and hears his story, she asks, incredulously, "And now that you're free...you're still a miner?” He responds, simply, “It is what I know” (O’Dell, 2004, p. 168).

\section{Modernism and Corporate Capitalism in Coal Run}

And here it is that post-industrial American fiction shows a relationship to postmodern American fiction. In the issue of living in ambiguity. The mine in fine and industrial society in large represent the height of the "project of modernity”, which David Harvey quotes Jürgen Habermas as defining as "the intellectual effort" begun in the Enlightenment "to develop objective science, universal morality and law, and autonomous art according to their inner logic" (Harvey, 1990, p. 12). The purpose was to promote the "scientific domination of nature" and "the development of rational forms of social organization and rational modes of thought" (p. 12) in "the name of human progress" (p. 13). This project, Harvey shows, continues through the industrial revolution of the 18th and 19th centuries and the 1913 introduction of assembly line production by Henry Ford. However, Modernism, from its earliest expressions in the 19th century-Harvey links the start to the Paris riots of 1848- 
began to recognize that the Enlightenment belief in eternal, universal verities and the inevitability of progress would not hold in a world of increasing complexity in scientific, mathematical, and technological advancement, in philosophical thought, and in international relations. That recognition reached its height after World War I when "in the absence of Enlightenment certitudes as to the perfectibility of man, the search for a myth appropriate to modernity became paramount” (p. 30). Harvey (1990) discusses at length the approaches between the world wars of various Modernist writers and artists to this quest for an appropriate myth and concludes that,

The "universal” or "high" modernism that became hegemonic after 1945 exhibited a much more comfortable relation to the dominant power centres in society. The contested search for an appropriate myth appeared to abate in part...because the international power system...itself became relatively stable. High modernist art, architecture, literature, etc. became establishment arts and practices in a society where a corporate capitalist version of the Enlightenment project of development for progress and human emancipation held sway as a political-economic dominant. (p. 35)

In the novel and the town of Coal Run, the "corporate capitalist” version of Modernism is represented by the $\mathrm{J} \& \mathrm{P}$ Coal Company and the industrial era of which it is a part and a symbol. The post-industrial generation of the town of Coal Run, the children of the miners who died in the mine explosion, even the few who have continued to try to follow that job path during the slow but steady decline of the J \& P Coal Company, then, are in very much the same relationship with the mine and the industrial era as the characters in Donald Barthelme's iconic novel about the shift from a Modernist to Postmodernist sensibility, The Dead Father, are to the figure and character of the Dead Father. Emblematic of Modernism, its passing, and its continuing influence, the Dead Father is, "Dead, but still with us, still with us, but dead” (Barthelme, 1975, p. 10). The contemporary generation in Coal Run, unlike their industrial era fathers, does not have the certainty of a job and a future that are clearly defined. Laid-off workers long to return to working the mines. Miners who have been laid off despair of finding, and, in fact, do not seem to be able to envision, any other source of employment, as one tells Ivan, "I only got called back nine months ago. I was out of work for almost a year before that...I can’t do it again. Being unemployed” (O’Dell, 2004, p. 20). There is an almost pathological inability to move on, a kind of catatonia, that affects a number of the next generation of characters.

\section{Catatonic Realism}

Catatonia is precisely the term used to characterize the ethos of one particular branch of postmodern American fiction, represented by writers like Raymond Carver, Ann Beattie, and Joyce Carol Oates by Alan Wilde in his influential 1981 book Horizons of Assent: Modernism, Postmodernism, and the Ironic Imagination. Specifically, Wilde (1981) defines their approach to rendering a chaotic world view in their fiction as "catatonic realism":

Assuming that things are as they must be, affirming and reaffirming...the reality of "the age”, ... [catatonic] realists reveal through their characters and in their own voices ... the experience, terrifying and reductive, of being controlled.... [and their] characters [display] a certain range of disabling but not, or not always, totaling crippling behavior.... (pp. 110-112)

And, clearly, many of the characters in Coal Run evince various forms of such behavior. Indeed, as Sherry Lee Linkon (2010) says, such disabling behaviors are a distinctive feature of deindustrialization fiction: "in most of these novels, family dysfunction and individual psychological struggles intertwine with economic limitations and decaying landscapes, illustrating the ways in which deindustrialization is at once personal, social, and economic” (p. 102). 
The characters in Coal Run and in similar novels of deindustrialization, I would contend, face exactly the same type of problem as human beings in the postmodern world. Specifically, the world that they knew-that they were born into, that their parents and grandparents lived in and based their own values and beliefs on - has dissipated, collapsed, somehow ceased to exist. But not completely. There are traces of it everywhere. That is, if forty ton steel shoots for loading coke onto railroad cars can in any reasonable sense be called a "trace".

\section{Conclusion: Moving Toward a Postmodern Sensibility}

These characters could continue on the path of Wilde's "catatonic realist", that is, living a life of disabling behaviors. Instead, though, I would posit that these post-industrial, postmodern characters are turning more to thinking in immediate and pragmatic ways that resemble most closely Alan Wilde's concept of "postmodern irony as suspense: an indecision about the meanings or relations of things is matched by a willingness to live with uncertainty, to tolerate, and in some cases, to welcome a world seen as random and multiple, even, at times, absurd” (p. 45). As Wilde quotes the character of Thomas in The Dead Father: "Things are not simple....Things are not done right, right things are not done. There are cases which are not clear. You must be able to tolerate the anxiety. To do otherwise is to jump ship, ethics-wise” (Wilde, 1981, p. 45). Wilde (1981) continues his point. “Tolerating the anxiety. It is a reasonable, if not complete, definition of the postmodern sensibility...” (p. 45).

And, indeed, it is precisely this "postmodern sensibility" that a number of the major characters, and, it may even be said, the entire group of townspeople in Coal Run adopt by the end of the novel. For example, the protagonist Ivan, a failed football hero, resists escaping into nostalgia for an athletic career that never was or could have been in favor of thinking in immediate and pragmatic ways. In spite of himself and his usual remoteness with women, Ivan tells his lady friend Chastity Morrison how he really feels about not being able to play football, noting that "the words were out before I can stop them. I realize it's the first time I've ever said them out loud to anyone” (p. 295). In encouragement and recognition of Ivan's local popularity, Chastity suggests that, with the current county sheriff planning to retire, "I think you'd make a good sheriff" (p. 297).

Another character who gradually makes the turn away from, in Alan Wilde's words, a "modernist spectator" to that of a "more active participant" (p. 15) is Val. A Vietnam veteran who suffers from catatonically disabling behavior, caught as he is between despair at the ruin of and nostalgia for the past glory and prosperity of the period of the mine and steel industries, by the end of the novel, he assents to the possibility of a relationship with Ivan's lovely and flirtatious sister, Jolene. As Ivan observes about Val's new affect, “For the first time since I've seen him again, there seems to be an emotion forming in his eyes. I'm not sure what the emotion is, but the blankness is breaking up" (p. 227).

But perhaps the most comprehensive example of postmodern assent can be seen at the very end of the novel. Every year, on the anniversary of the mine disaster, the residents of Coal Run return to the entrance of the mine to commemorate their dead. Ivan describes this change in the morning traffic:

I notice more cars and trucks on the road than usual, but I don't think much of it....I follow [Jolene's] eyes to the remains of Gertie. Cars and trucks are parked all around it, in the same haphazard fashion they were left in the day of the explosion....I begin to see the people. From this distance they're the size of ants....In my mind I know who they are. I see husbands and wives getting out of their cars and holding hands. Guys running into other guys, buddies, coworkers, school chums, shaking hands. Daughters helping their elderly mothers, holding them at their elbows where their big white spring pocketbooks hang.... Kids running off with their friends. A group of teenage girls casting glances at a group of teenage boys. (pp. 360-362) 
This passage expresses the essence of a sensibility that, as Wilde (1981) says of postmodern irony, "leads to a double and seemingly contradictory progression which, on the one hand, demands the recognition of the increasing disintegration of an already disjunct world, and, on the other, not only submits but ....assents to it, or to its inherent possibilities” (pp. 15-16). It is in this sense of what, perhaps surprisingly, may be seen as an affirmative response to a dramatically altered socio-economic world, then, that I wish to suggest a significant linkage between the characters and situations of postindustrial fiction and those of postmodern fiction, a linkage of finding the courage to go forward rather than to stagnate, to opt for hope rather than to settle for despair, and to take a chance that there may be the possibility of a better, if attenuated, tomorrow than today.

\section{References}

Barthelme, D. (1975). The dead father. New York, NY: Pocket Books.

Harvey, D. (1990). The condition of postmodernity: An enquiry into the origins of social change. Maldon, MA: Blackwell.

Linkon, S. Lee. (2010). And their children after them: Deindustrialization lit. New Labor Forum, 19(1), 102-105, 127.

Linkon, S. Lee. (2014) Narrating past and future: Deindustrialized landscapes as resources. International Labor and Working-Class History, 84, 38-54.

O’Dell, Tawni. (2004). Coal Run. New York, NY: New American Library.

Parnaby, A. (2013). Life among the ruins: Deindustrialization in historiographical perspective. Labour, 72, 279-293, 298.

Wilde, A. (1981). Horizons of assent: Modernism, postmodernism, and the ironic imagination. Baltimore, MD: The Johns Hopkins University Press. 